\title{
Use of Acid-Suppressive Drugs and Risk of Fracture: A Meta-analysis of Observa- tional Studies
}

Cbun-Sick Eom, MD, MPH

Sang Min Park, MD, MPH, $P b D^{1}$

Seung-Kwon Myung, MD, MS $S^{1,2}$

Jae Moon Yun, MD

Jeong-Soo Abn, MD, MS

'Department of Family Medicine, Seoul National University Hospital, Seoul National University College of Medicine, Seoul, Republic of Korea

${ }^{2}$ Cancer Epidemiology Branch and Center for Cancer Prevention and Detection, Research Institute and Hospital, National Cancer Center, Goyang, Republic of Korea

Conflicts of interest: authors report none.

\section{CORRESPONDING AUTHORS*}

Sang Min Park, MD, MPH, PhD Department of Family Medicine Seoul National University Hospital Seoul National University College of Medicine

101 Daehangno, Jongno-gu Seoul, 110-744, Republic of Korea sangmin.park.snuh@gmail.com

Seung-Kwon Myung, MD, MS Cancer Epidemiology Branch and Center for Cancer Prevention and Detection Research Institute and Hospital

National Cancer Center

323 Ilsan-ro, Ilsandong-gu

Goyang, Gyeonggi

410-769, Republic of Korea

msk@ncc.re.kr

*Drs Park and Myung contributed equally to this paper as corresponding authors.

\begin{abstract}
PURPOSE Previous studies have reported inconsistent findings regarding the association between the use of acid-suppressive drugs such as proton pump inhibitors (PPIs) and histamine 2 receptor antagonists $\left(\mathrm{H}_{2} \mathrm{RAs}\right)$ and fracture risk. We investigated this association using meta-analysis.
\end{abstract}

METHODS We searched MEDLINE (PubMed), EMBASE, and the Cochrane Library from inception through December 2010 using common key words. We included case-control, nested case-control, and cohort studies. Two evaluators independently reviewed and selected articles. We determined pooled effect estimates by using random-effects meta-analysis, because of heterogeneity.

RESULTS Of 1,809 articles meeting our initial inclusion criteria, 5 case-control studies, 3 nested case-control studies, and 3 cohort studies were included in the final analyses. The pooled odds ratio (OR) for fracture was 1.29 (95\% confidence interval [Cl], 1.18-1.41) with use of PPIs and $1.10(95 \% \mathrm{Cl}, 0.99-1.23)$ with use of $\mathrm{H}_{2} \mathrm{RAs}$ when compared with nonuse of the respective medications. Long-term use of PPIs increased the risk of any fracture (adjusted OR $=1.30 ; 95 \% \mathrm{Cl}, 1.15-1.48$ ) and hip fracture risk (adjusted $\mathrm{OR}=1.34 ; 95 \% \mathrm{Cl}, 1.09-1.66$ ), whereas long-term $\mathrm{H}_{2} \mathrm{RA}$ use was not significantly associated with fracture risk.

CONCLUSIONS We found possible evidence linking PPI use to an increased risk of fracture, but no association between $\mathrm{H}_{2} \mathrm{RA}$ use and fracture risk. Widespread use of PPIs with the potential risk of fracture is of great importance to public health. Clinicians should carefully consider their decision to prescribe PPIs for patients already having an elevated risk of fracture because of age or other factors.

Ann Fam Med 2011;9:257-267. doi:10.1370/afm.1243.

\section{INTRODUCTION}

$\mathrm{R}$ ecently, the medical literature has paid considerable attention to unrecognized adverse effects of commonly used medications and their potential public health impact. ${ }^{1}$ Osteoporosis is one such potential adverse effect. It is a common and important source of morbidity in the population in general, particularly among older adults. More than $40 \%$ of women and $14 \%$ of men older than 50 years of age experience fractures related to osteoporosis. ${ }^{2}$ Osteoporotic fractures of the spine frequently occur in both men and women. ${ }^{3}$

Acid-suppressive drugs (ASDs) represent the second leading medication worldwide in terms of sales, with the value totaling $\$ 26.9$ billion in 2005. ${ }^{4}$ Proton pump inhibitors (PPIs) and histamine 2 receptor antagonists $\left(\mathrm{H}_{2} \mathrm{RAs}\right)$ are the most popular ASDs available, and millions of individuals currently take these medications on a continuous or long-term basis. ${ }^{5}$ These potent drugs are used to treat various disorders, and indications for long-term maintenance therapy with this drug class continue to expand. ${ }^{6}$

The relationship between ASD use and bone health remains unclear. 
Some findings raise the possibility that PPIs may prevent osteoporosis and fractures. Several in vitro and animal studies have suggested that PPIs may decrease bone resorption by inhibiting osteoclastic vacuolar $\mathrm{H}+/ \mathrm{K}+$ ATPase activity. ${ }^{7-11}$ Osteoclasts possess proton pumps, which are used during the excretion of $\mathrm{H}_{+}$ ions for bone resorption. Osteoclast-selective PPIs may therefore be used as antiresorptive agents ${ }^{12}$ with the potential of preventing fractures. ${ }^{13-16}$ Administration of a selective inhibitor of the osteoclastic vacuolar $\mathrm{H}_{+} /$ $\mathrm{K}+$ ATPase prevents bone loss in ovariectomized rats, an animal model representative of postmenopausal osteoporosis. ${ }^{15}$ As bone resorption is necessary for the development of normal bone microstructure, however, one may speculate that PPI-induced blockade of the osteoclast-associated vacuolar proton pump may actually increase fracture risk. ${ }^{17}$

It has been reported that ASDs may interfere with bone metabolism and thus increase fracture risk. Some potential mechanisms by which PPI therapy may lead to fractures have been identified. First, the small intestine's ability to absorb ingested calcium salts depends on $\mathrm{pH} .{ }^{18,19}$ Calcium solubility is believed to be important for its absorption, ${ }^{20}$ and an acidic environment in the gastrointestinal tract facilitates the release of ionized calcium from insoluble calcium salts. ${ }^{21}$ Second, impaired calcium absorption might lead to compensatory secondary hyperparathyroidism, which may increase the rate of osteoclastic bone resorption. Third, PPIs may interfere with the resorptive activity of osteoclasts. Without osteoclast activity, old bone cannot be replaced, predisposing patients to fractures. ${ }^{17,22}$ Further research is required to determine the precise effect of long-term use of PPIs on bone mineral metabolism, however. ${ }^{23}$ Fourth, gastric parietal cells appear to have a potent endocrine role in secreting estrogens. ${ }^{24-27}$ Atrophy of the gastric mucosa, observed in patients infected with CagA-positive Helicobacter pylori, ${ }^{28}$ reduces the number of gastric parietal cells and may decrease local production of estrogens. Estrogens produced in the stomach directly induce expression and production of ghrelin, ${ }^{29,30}$ which appears to increase bone formation by osteoblasts. ${ }^{31}$

PPIs target the $\mathrm{H}+\mathrm{K}+$ ATPase of gastric parietal cells and inhibit the final step in gastric proton release. ${ }^{32}$ Standard doses of these drugs can reduce gastric acid secretion by up to $98 \%$ by irreversibly deactivating the proton pump of gastric parietal cells. ${ }^{33}$ Marked hypochlorhydria, particularly among the elderly population, who might have a decreased clearance of PPIs and be more likely to have hypochlorhydria at baseline because of a higher prevalence of $H$ pylori infection, ${ }^{34,35}$ could theoretically result in calcium malabsorption. ${ }^{36,37} \mathrm{H}_{2}$ RAs could potentially have similar effects, although they are less potent acid suppressants, blocking $70 \%$ of gastric acid production. ${ }^{38}$

Observational studies have yielded inconclusive results regarding the association between use of ASDs and fracture risk, with reported adjusted odds ratios (ORs) or relative risks (RRs) ranging widely, from 0.88 to 3.10 . Some epidemiologic studies have found that PPI therapy is associated with an increased risk of hip fractures, ${ }^{22,23,39-41}$ whereas a nested case-control study did not find any significant association. ${ }^{42}$ To our knowledge, no meta-analysis of such studies has been conducted. We therefore investigated the association between the use of PPIs or $\mathrm{H}_{2} \mathrm{RAs}$ and fracture risk by performing a meta-analysis of observational studies.

\section{METHODS}

We followed the MOOSE (Meta-analysis of Observational Studies in Epidemiology) guidelines ${ }^{43}$ during all stages of design, implementation, and reporting of this meta-analysis.

\section{Literature Search}

We searched MEDLINE (PubMed) (inception to December 2010), EMBASE (inception to December 2010), and the Cochrane Library (inception to December 2010) by using common key words related to ASDs and fracture risk. The key words for ASDs were as follows: " $\mathrm{H}_{2}$ blocker or histamine-2 receptor antagonists or cimetidine or ranitidine or famotidine or nizatidine or proton pump inhibitors or proton pumps or omeprazole or Nexium or lansoprazole or rabeprazole or pantoprazole or esomeprazole." The key words for fracture risk were as follows: "osteoporosis or osteopenia or fracture risk or fractures or fracture rates or bone health or bone metabolism or bone mineral density." We did not limit the search through use of any restrictions.

\section{Study Selection}

We planned to (1) include randomized controlled trials (RCTs) and cohort, nested case-control, and case-control studies that investigated the association between the use of ASDs such as PPIs or $\mathrm{H}_{2}$ RAs and fracture risk and (2) develop a list of the types of fracture outcomes reported in the studies with the adjusted ORs or RRs and 95\% confidence interval (CIs). Two of the authors (C-S.E. and J-S.A.) independently evaluated the eligibility of all studies retrieved from the databases on the basis of selection criteria.

\section{Data Extraction and Quality Assessment}

We extracted data from the selected articles on the following items: the first author's last name, publication year, country where the study was performed, study 
design, study period, type of outcome (fracture of the hip, vertebrae, wrist, or any site), type of agent (PPI or $\mathrm{H}_{2} \mathrm{RA}$ ), adjusted $\mathrm{OR}$ and $\mathrm{RR}$ with CIs, number of variables adjusted for in the analysis, the case individuals and control individuals with or without exposure, and duration of exposure.

Long-term use was defined as use for more than 1 year before the index date. We chose this duration because alterations in fracture risk due to the use of other medications, such as bisphosphonates, thiazide diuretics, and corticosteroids, become apparent after 1 year of exposure..$^{44,45}$ In studies wherein users did not use the PPI or $\mathrm{H}_{2} \mathrm{RA}$ for more than 1 year, we chose the longest available period of use.

Two investigators (C-S.E. and S.M.P.) independently extracted data by using a standardized data collection form. We resolved disagreements by mutual discussion and, if required, by consulting a third investigator.

We assessed the methodologic quality of included studies by using the Newcastle-Ottawa Scale (NOS) for determining the quality of case-control and cohort studies in meta-analyses. ${ }^{46}$ We considered studies having a total score of greater than 7 to be high-quality studies, as standard criteria have not been established and the mean total score for all 11 studies assessed was 7.18.

\section{Main and Subgroup Analyses}

We investigated the association between the use of PPIs, $\mathrm{H}_{2} \mathrm{RAs}$, or both and the risk of fracture by using adjusted data for the main analyses. We also performed subgroup analyses by type of study (case-control, nested case-control, or cohort study), methodologic quality of the study (high vs low), number of variables used for statistical adjustment $(\geq 5 \mathrm{vs}<5)$, type of agent (PPI vs $\mathrm{H}_{2} \mathrm{RA}$ ), fracture outcome, medication dose, and sex.

\section{Statistical Analysis}

We assumed that ORs approximated RRs and therefore combined the study estimates regardless of which measure of association was reported because the incidence of the outcomes of interest was sufficiently rare ( $<5 \%$ per year). Pooled effect estimates were obtained by using random-effects meta-analysis, because of heterogeneity.

We examined the heterogeneity of results across studies by using the Higgins $\mathrm{I}^{2}$, which measures the percentage of total variation across studies. ${ }^{47}$ The DerSimonian and Laird method ${ }^{48}$ for calculating summary measures was used in the random-effects models. We evaluated the publication bias of the studies included in the final analysis by using the Begg funnel plot and the Egger test. We used the Stata SE version 10.1 software package (StataCorp, College Station, Texas) for statistical analysis.

\section{RESULTS}

\section{Characteristics of the Included Studies}

We originally planned to include RCTs in this metaanalysis; however, as of the end of our search period, no RCTs on this topic had been reported.

Figure 1 shows how we selected relevant studies for inclusion in the meta-analysis. A total of 1,809 articles were identified by searching the 3 databases. We excluded 170 duplicate articles and an additional 1,621 articles that did not meet the selection criteria. We reviewed the full texts of the remaining 18 articles. Of these, 7 articles were excluded. The remaining 11 studies were included in the final analysis. $22,23,39 \cdot-42,49,50-53$

Table 1 summarizes the general characteristics

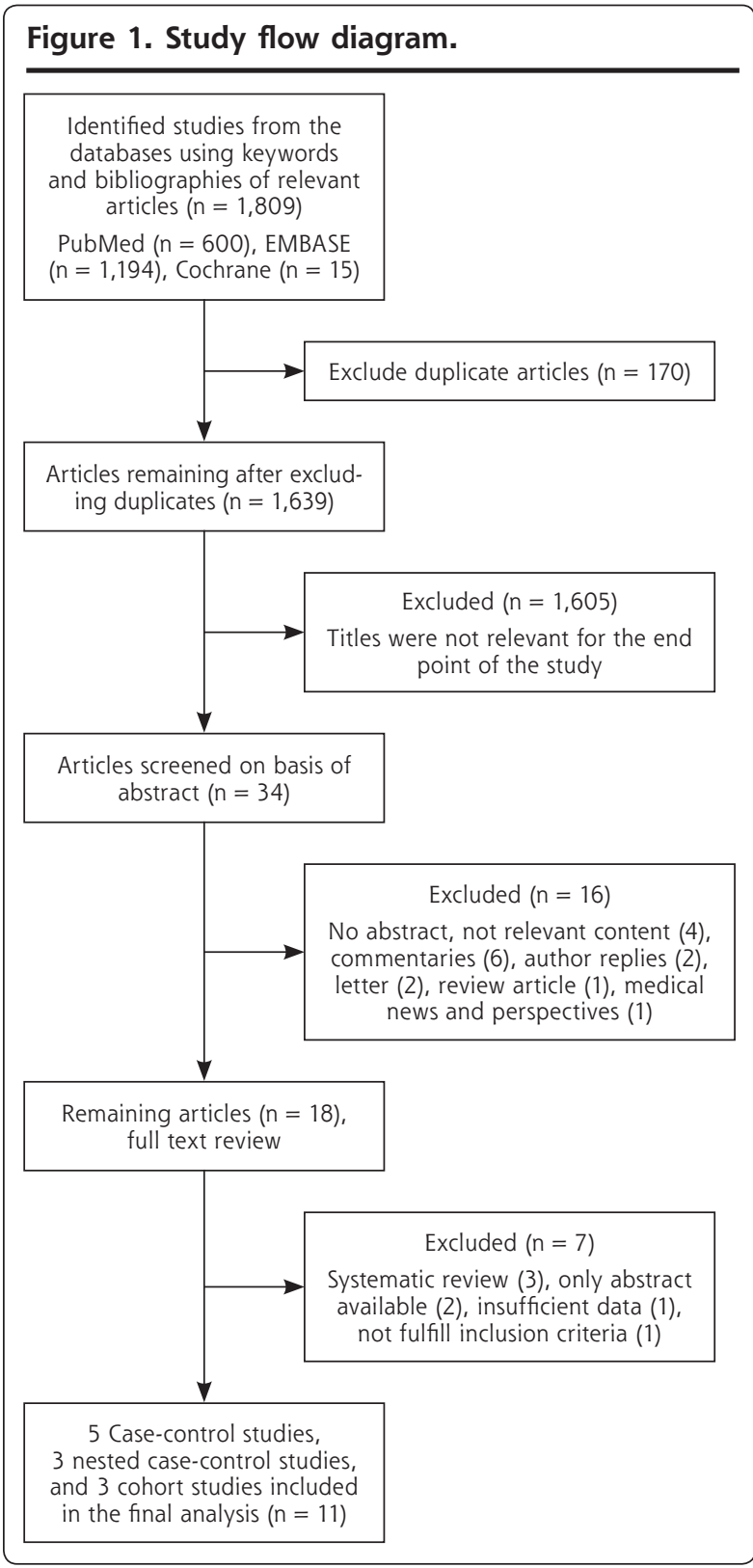


Table 1. Characteristics of Studies Included in the Final Analysis $(\mathrm{N}=11)$

\begin{tabular}{|c|c|c|c|c|}
\hline Study & $\begin{array}{l}\text { Country; Study } \\
\text { Design or Setting }\end{array}$ & $\begin{array}{l}\text { Study } \\
\text { Years }\end{array}$ & Outcome and Ascertainment & $\begin{array}{l}\text { Agent and } \\
\text { Comparison }\end{array}$ \\
\hline $\begin{array}{l}\text { Grisso et al, }{ }^{49} \\
\quad 1997\end{array}$ & $\begin{array}{l}\text { USA; HCC; Kaiser Perma- } \\
\text { nente, northern Califor- } \\
\text { nia; men aged } \geq 45 \text { y }\end{array}$ & 1991-1993 & $\begin{array}{l}\text { Outcome: hip fracture } \\
\text { Ascertainment: radiologically confirmed diagnosis }\end{array}$ & $\begin{array}{l}\text { Agent: cimetidine } \\
\text { Comparison: ever use } \\
\text { vs never use }\end{array}$ \\
\hline $\begin{array}{l}\text { Vestergaard } \\
\text { et al, }{ }^{39} 2006\end{array}$ & $\begin{array}{l}\text { Denmark; PCC; whole } \\
\text { population }\end{array}$ & 2000 & $\begin{array}{l}\text { Outcome: hip fracture, spine fracture, forearm frac- } \\
\text { ture, any fracture } \\
\text { Ascertainment: insurance code using ICD system }\end{array}$ & $\begin{array}{l}\text { Agent: PPIs, } \mathrm{H}_{2} \mathrm{RA} \text {, other } \\
\text { antacids, antihistamines, } \\
\text { and NSAIDs } \\
\text { Comparison: last use } \\
<1 \text { y ago vs nonuse }\end{array}$ \\
\hline
\end{tabular}

\begin{tabular}{|c|c|c|c|c|}
\hline $\begin{array}{l}\text { Yang et al, }{ }^{22} \\
2006\end{array}$ & $\begin{array}{l}\text { UK; NCC; GPRD; patients } \\
\text { aged } \geq 50 \text { y }\end{array}$ & $1987-2003$ & $\begin{array}{l}\text { Outcome: hip fracture } \\
\text { Ascertainment: confirmed by general practitioners }\end{array}$ & $\begin{array}{l}\text { Agent: PPIs and } \mathrm{H}_{2} \mathrm{RAs} \\
\text { Comparison: user } \\
(>1 \text { y) vs nonuser }\end{array}$ \\
\hline $\begin{array}{l}\text { Kaye and } \\
\text { Jick, } 2008\end{array}$ & $\begin{array}{l}\text { UK; NCC; GPRD; patients } \\
\text { aged 50-79 y }\end{array}$ & 1995-2005 & $\begin{array}{l}\text { Outcome: hip fracture } \\
\text { Ascertainment: computerized medical records (Oxford } \\
\text { Medical Information System or Read codes) }\end{array}$ & $\begin{array}{l}\text { Agent: PPIs } \\
\text { Comparison: any PPI pre- } \\
\text { scription vs no prescription }\end{array}$ \\
\hline $\begin{array}{l}\text { Targownik et } \\
\mathrm{al}^{23} 2008\end{array}$ & $\begin{array}{l}\text { Canada; PCC; patients } \\
\text { aged } \geq 50 \text { y }\end{array}$ & $1996-2004$ & $\begin{array}{l}\text { Outcome: fractures of hip, vertebra, and wrist } \\
\text { Ascertainment: physician or hospital admission with } \\
\text { a diagnosis of osteoporosis-related fractures (ICD } \\
\text { system) }\end{array}$ & $\begin{array}{l}\text { Agent: PPIs } \\
\text { Comparison: user vs nonuser }\end{array}$ \\
\hline $\begin{array}{l}\text { Yu et al, }{ }^{40} \\
2008\end{array}$ & $\begin{array}{l}\text { USA; cohort; men and } \\
\text { women aged } \geq 65 \mathrm{y}\end{array}$ & 1986-2007 & $\begin{array}{l}\text { Outcome: nonspine and hip fracture } \\
\text { Ascertainment: review of radiographic reports or } \\
\text { radiologist }\end{array}$ & $\begin{array}{l}\text { Agent: PPIs and } \mathrm{H}_{2} \mathrm{RAs} \\
\text { Comparison: user vs nonuser }\end{array}$ \\
\hline $\begin{array}{l}\text { Roux et al, }{ }^{41} \\
2009\end{array}$ & $\begin{array}{l}\text { France; cohort; women } \\
\text { aged } 55-79 \text { y }\end{array}$ & 1999-2007 & $\begin{array}{l}\text { Outcome: vertebral fracture } \\
\text { Ascertainment: } 2 \text { radiologists }\end{array}$ & $\begin{array}{l}\text { Agent: omeprazole } \\
\text { Comparison: user vs nonuser }\end{array}$ \\
\hline $\begin{array}{l}\text { Gray et al, }{ }^{51} \\
2010\end{array}$ & $\begin{array}{l}\text { USA; cohort; Women's } \\
\text { Health Initiative; } \\
\text { women aged } 50-79 \text { y }\end{array}$ & 1993-2005 & $\begin{array}{l}\text { Outcome: hip, spine, forearm, or wrist fracture } \\
\text { Ascertainment: review of radiology reports }\end{array}$ & $\begin{array}{l}\text { Agent: PPIs and } \mathrm{H}_{2} \mathrm{RAs} \\
\text { Comparison: user vs nonuser }\end{array}$ \\
\hline $\begin{array}{l}\text { Corley et al, } \\
2010\end{array}$ & $\begin{array}{l}\text { USA; NCC; Kaiser Per- } \\
\text { manente, northern } \\
\text { California }\end{array}$ & 1995-2007 & $\begin{array}{l}\text { Outcome: hip/femur fracture } \\
\text { Ascertainment: electronic coding }\end{array}$ & $\begin{array}{l}\text { Agent: PPIs and } \mathrm{H}_{2} \mathrm{RAs} \\
\text { Comparison: user vs nonuser }\end{array}$ \\
\hline $\begin{array}{l}\text { Chiu et al, } \\
2010\end{array}$ & $\begin{array}{l}\text { Taiwan; PCC; patients } \\
\text { aged } \geq 50 \text { y }\end{array}$ & $2005-2006$ & $\begin{array}{l}\text { Outcome: hip fracture } \\
\text { Ascertainment: ICD code for National Health } \\
\text { Insurance }\end{array}$ & $\begin{array}{l}\text { Agent: PPIs } \\
\text { Comparison: user vs nonuser }\end{array}$ \\
\hline $\begin{array}{l}\text { Pouwels } \\
\text { et al, }{ }^{52} 2011\end{array}$ & Netherlands; PCC & 1991-2002 & $\begin{array}{l}\text { Outcome: hip/femur fracture } \\
\text { Ascertainment: ICD code }\end{array}$ & $\begin{array}{l}\text { Agent: PPIs and } \mathrm{H}_{2} \mathrm{RAs} \\
\text { Comparison: current use vs } \\
\text { never use }\end{array}$ \\
\hline
\end{tabular}

never use
Comparison: current use vs

$\mathrm{BMI}=$ body mass index $; \mathrm{CHF}=$ congestive heart failure; $\mathrm{COPD}=$ chronic obstructive pulmonary disease; $\mathrm{CRF}=$ chronic renal failure; $\mathrm{DMARD}=$ disease-modifying antirheumatic drug; GPRD = General Practice Research Database; $\mathrm{HCC}=$ hospital-based case-control; ICD = International Classification of Diseases; $\mathrm{H}_{2} \mathrm{RA}=$ histamine 2 receptor antagonist; HRT = hormone replacement therapy; $\mathrm{MI}=$ myocardial infarction; MrOS = Osteoporotic Fractures in Men study; na = not available; $\mathrm{NCC}=$ nested case-control; $\mathrm{NSAID}=$ nonsteroidal anti-inflammatory drug; $\mathrm{OR}=$ odds ratio; $\mathrm{PCC}=$ population-based case-control; $\mathrm{PPI}=$ proton pump inhibitor; $\mathrm{RA}=$ rheumatoid arthritis; $\mathrm{RR}=$ relative risk; SOF = Study of Osteoporotic Fractures.

${ }^{a}$ Combined OR with $95 \% \mathrm{Cl}$ calculated from data set. 


\section{Adjusted OR or RR $(95 \% \mathrm{Cl})$}

$2.00(1.0-4.4)$

PPIS

Total: 1.18 (1.1-1.4)

Hip: 1.45 (1.3-1.7)

Spine: $1.60(1.3-2.0)$

Forearm: 0.95 (0.8-1.1)

$\mathrm{H}_{2} \mathrm{RAs}$

Total: $0.88(0.8-0.95)$

Hip: 0.69 (0.6-0.8)

Spine: $1.00(0.7-1.4)$

Forearm: 0.90 (0.7-1.1)

PPIs: 1.44 (1.3-1.6)

$\mathrm{H}_{2}$ RAs: 1.23 (1.1-1.4)

$0.90(0.7-1.1)$

Exposure $\geq 7 \mathrm{y}$

Hip + vertebra + wrist: 1.92 (1.2-3.2)

Hip + vertebra: 2.47 (1.2-5.1)

Hip: 4.55 (1.7-12.3)

PPIs

Nonspine: $1.3(1.1-1.53)^{\mathrm{a}}$

Hip: $1.05(0.8-1.5)^{a}$

$\mathrm{H}_{2}$ RAs

Nonspine: 1.04 (0.9-1.2)

Hip: $1.26(0.9-1.7)^{\text {a }}$

$3.10(1.1-8.4)$

PPIs

Total: 1.25 (1.2-1.4)

Hip: 1.00 (0.7-1.4)

Spine: 1.47 (1.2-1.8)

Forearm or wrist: 1.26 (1.1-1.5)

$\mathrm{H}_{2} \mathrm{RAs}$

Total: 1.08 (1.0-1.1)

Hip: 1.07 (0.9-1.3)

Spine: 1.02 (0.9-1.2)

Forearm or wrist: 1.05 (0.9-1.2)

PPIS

Hip: 1.30 (1.21-1.39)

$\mathrm{H}_{2} \mathrm{RAs}$

Hip: 1.18 (1.08-1.29)

$2.11(1.45-3.07)$

PPIS

Hip: 1.20 (1.04-1.4)

$\mathrm{H}_{2}$ RAs

Hip: 1.19 (1.00-1.4)

\section{Adjustment Variables}

Age category, zip code or telephone exchange, age as a continuous variable, and BMI

Alcoholism; working or not; Charlson index; ever use of antiepileptic drugs, anxiolytics or sedatives, antidepressants, neuroleptics, corticosteroids; number of bed-days in 1999; number of contacts to general practitioner or specialist in 1999; living with someone or alone; prior fracture; education level; and income in 1999

Age, sex, BMI, medication use, and health condition

Age, sex, smoking, and BMI

Area of residence, income, comorbidity, home care services, medications that might have affected the risk of osteoporosis or fracture

Age, clinic, race, BMI, alcohol, exercise, corticosteroids, NSAIDs, calcium supplement, osteoporosis medication, self-reported health, initial total hip BMD, weight change, (SOF; caffeine, estrogen), (MrOS; smoking, history of stomach surgery)

BMI, history of clinical low-trauma fracture, steroids, thiazide, thyroid hormone, calcium, vitamin D, smoking, alcohol, self-reported falls and health poor to fair, baseline lumbar spine T score, spine and/or hip T score $\leq 2.5$

Age, race/ethnicity, BMI, enrollment in clinical trial status, indicator for cohort, smoking, physical activity, self-reported health, having a parent who broke a hip after age $40 y$, treated diabetes mellitus, history of fracture at 55 y or older, corticosteroid use, physical function score, history of MI or angina, asthma or emphysema, arthritis, stomach or duodenal ulcer, moderate or severe heartburn, osteoporosis, number of psychoactive medications, use of HRT and bisphosphonates

Age, sex, smoking, alcohol abuse, diabetes, arthritis, kidney disease, ethnicity, medications

Age, sex, hypertension, diabetes, stroke, asthma, COPD, CHF, MI, dementia, depression, CRF, NSAID, corticosteroids, anticoagulants, diuretics, antipsychotics, thyroxine, HRT, statins, antihypertensive medications, sedatives, bisphosphonates

Use of other antacids, average daily dose of oral corticosteroids, anxiolytics/hypnotics, short- or long-acting benzodiazepines, HRT, anticonvulsants, antipsychotics, antidepressants, $\beta$-blockers, antidiabetics, $\geq 2$ NSAIDs, DMARDs, a history of digestive system disorders, anemia, mental disorders, cerebrovascular disease, CHF, endocrine disorders, RA, diabetes mellitus, COPD and inflammatory bowel disease. Furthermore, the PPI analysis was adjusted for the use of $\mathrm{H}_{2} \mathrm{RAs}$ and the $\mathrm{H}_{2} \mathrm{RA}$ analysis for the use of PPIs
Exposed and Unexposed Case/Control, $\mathrm{n}$

Exposed: $39 / 26$

Unexposed: $317 / 376$

Exposed: PPIs: 14,557/29,784

$\mathrm{H}_{2}$ RAs: $11,202 / 26,333$

Unexposed: PPIs: 10,098/344,178

$\mathrm{H}_{2}$ RAs: $113,453 / 347,629$

Exposed: PPIs: 571/3,351

$\mathrm{H}_{2} \mathrm{RAs}: 732 / 4,478$

Unexposed: PPIs: 12,985/132,035

$\mathrm{H}_{2} \mathrm{RA}: 12,824 / 130,908$

Exposed: $132 / 1,428$

Unexposed: 966/9,495

Exposed: $415 / 872$

Unexposed: 12,963/39,176

na

Exposed: risk among exposed $=14 / 61$

Unexposed: risk among unexposed $=128 / 1,150$

na

Exposed: PPIs: $1,558 / 4,806$ $\mathrm{H}_{2} \mathrm{RAs:} 875 / 3,061$ Unexposed: PPIs: $32,194 / 125,665$ $\mathrm{H}_{2} \mathrm{RAs}$ : $32,877 / 127,410$

na

Exposed: PPIs: 305/773

$\mathrm{H}_{2}$ RAs: $196 / 520$

Unexposed: PPIs: 5,810/23,430

$\mathrm{H}_{2}$ RAs: $5,624 / 22,545$ 
of the 11 studies included in the meta-analysis. We identified 5 case-control studies, ${ }_{1}^{23,39,49,52,53} 3$ nested case-control studies, ${ }^{22,42,50}$ and 3 cohort studies. ${ }^{40,41,51}$ The selected studies were published between 1997 and 2011, spanning 14 years. Six studies $22,39,40,50-52$ evaluated PPIs and $\mathrm{H}_{2} \mathrm{RAs}_{;} 4$ studies ${ }^{23,41,42,53}$ evaluated PPIs only; and 1 study ${ }^{49}$ evaluated $\mathrm{H}_{2}$ RAs only.

\section{Main Analysis}

As shown in Figure 2, the overall use of PPIs was associated with a significantly increased risk of any fracture in a random-effects model meta-analysis of 4 case-control studies, 3 nested case-control studies, and 3 cohort studies (adjusted $\mathrm{OR}=1.29 ; 95 \% \mathrm{CI}, 1.18-1.41 ; \mathrm{I}^{2}=69.8 \%$; $\mathrm{n}=10$ ). Use of $\mathrm{H}_{2} \mathrm{RAs}$ was not associated with an increased fracture risk, however (adjusted OR $=1.10 ;$ 95\% CI, 0.99-1.23; $\mathrm{I}^{2}=86.3 \% ; \mathrm{n}=7$ ).

\section{Subgroup Meta-Analyses}

Table 2 shows the association between PPIs or $\mathrm{H}_{2} \mathrm{RAs}$ and the risk of fracture in subgroup meta-analyses.

When studies were grouped by type, we observed a positive association between the use of PPIs and fracture risk in all types, but a positive association between the use of $\mathrm{H}_{2}$ RAs and fracture risk only when nested case-control studies were combined (adjusted OR $=1.20 ; 95 \%$ CI, $1.13-1.28 ; \mathrm{I}^{2}=0.0 \% ; \mathrm{n}=2$ ) or when cohort studies were combined (adjusted $\mathrm{OR}=1.08 ; 95 \% \mathrm{CI}, 1.02-1.13 ; \mathrm{I}^{2}=0.0 \%$; $\mathrm{n}=2$ ). In contrast, no significant association was observed in case-control studies (adjusted OR $=1.11 ; 95 \% \mathrm{CI}, 0.81-1.51$; $\mathrm{I}^{2}=85.6 \% ; \mathrm{n}=3$ ).

Grouping of studies by methodologic quality (scores are given in Table 3 ) showed a significantly increased fracture risk with PPI use in both high-quality studies (adjusted OR $=1.32 ; 95 \% \mathrm{CI}, 1.18$ $\left.1.47 ; \mathrm{I}^{2}=63.7 \% ; \mathrm{n}=5\right)$ and low-quality studies (adjusted OR $=1.25 ; 95 \% \mathrm{CI}, 1.06$ $\left.1.48 ; \mathrm{I}^{2}=78.7 \% ; \mathrm{n}=5\right)$. There was also a significant positive association between $\mathrm{H}_{2} \mathrm{RA}$ use and fracture risk in high-quality studies (adjusted OR $=1.13 ; 95 \% \mathrm{CI}$, $\left.1.05-1.21 ; \mathrm{I}^{2}=40.3 \% ; \mathrm{n}=3\right)$ but not in lowquality ones (adjusted OR $=1.09 ; 95 \% \mathrm{CI}$, $\left.0.87-1.38 ; \mathrm{I}^{2}=90.6 \% ; \mathrm{n}=4\right)$.

Grouping studies by the number of adjustment variables revealed a significantly increased fracture risk in those adjusting for at least 5 variables for both PPI use (adjusted OR $=1.36$; 95\% CI, $1.24-1.49 ; \mathrm{I}^{2}=63.0 \% ; \mathrm{n}=6$ ) and $\mathrm{H}_{2} \mathrm{RA}$ use (adjusted $\left.\mathrm{OR}=1.14 ; 95 \% \mathrm{CI}, 1.06-1.22 ; \mathrm{I}^{2}=57.7 \% ; \mathrm{n}=4\right)$. In studies adjusting for fewer than 5 variables, there was
Figure 2. PPIs or $\mathrm{H}_{2} \mathrm{RAs}$ use and the combined risk of any fracture in a random-effects model meta-analysis of casecontrols studies and cohort studies.
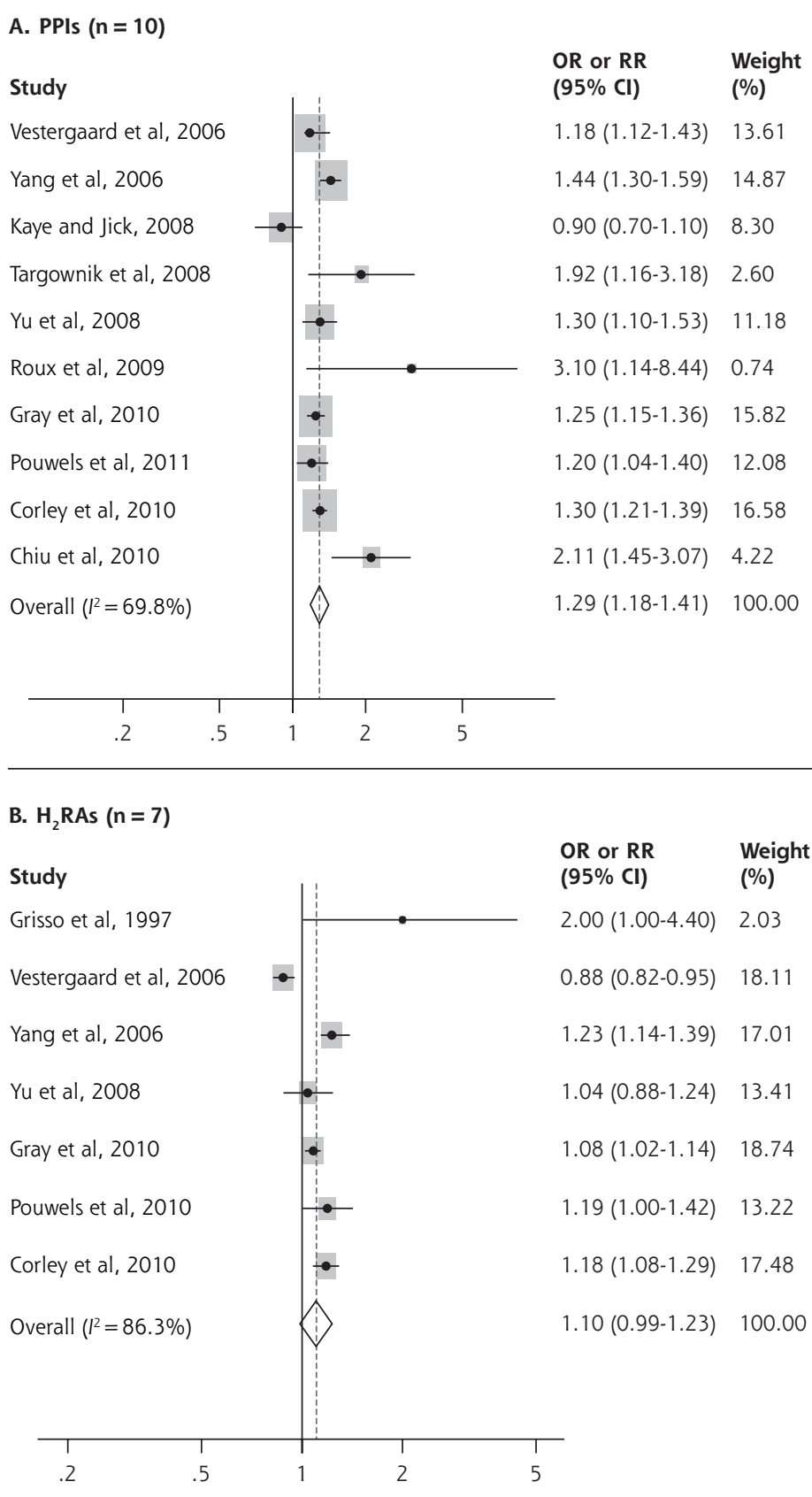

$\mathrm{Cl}=$ confidence interval; $\mathrm{H}_{2} \mathrm{RA}=$ histamine 2 receptor antagonist; $\mathrm{OR}=$ odds ratio; $\mathrm{PPI}=$ proton pump inhibitor; $\mathrm{RR}=$ relative risk. 
Table 2. PPI or $\mathrm{H}_{2} \mathrm{RA}$ Use and the Risk of Fracture in Subgroup Meta-analyses Using a Random-Effects Model

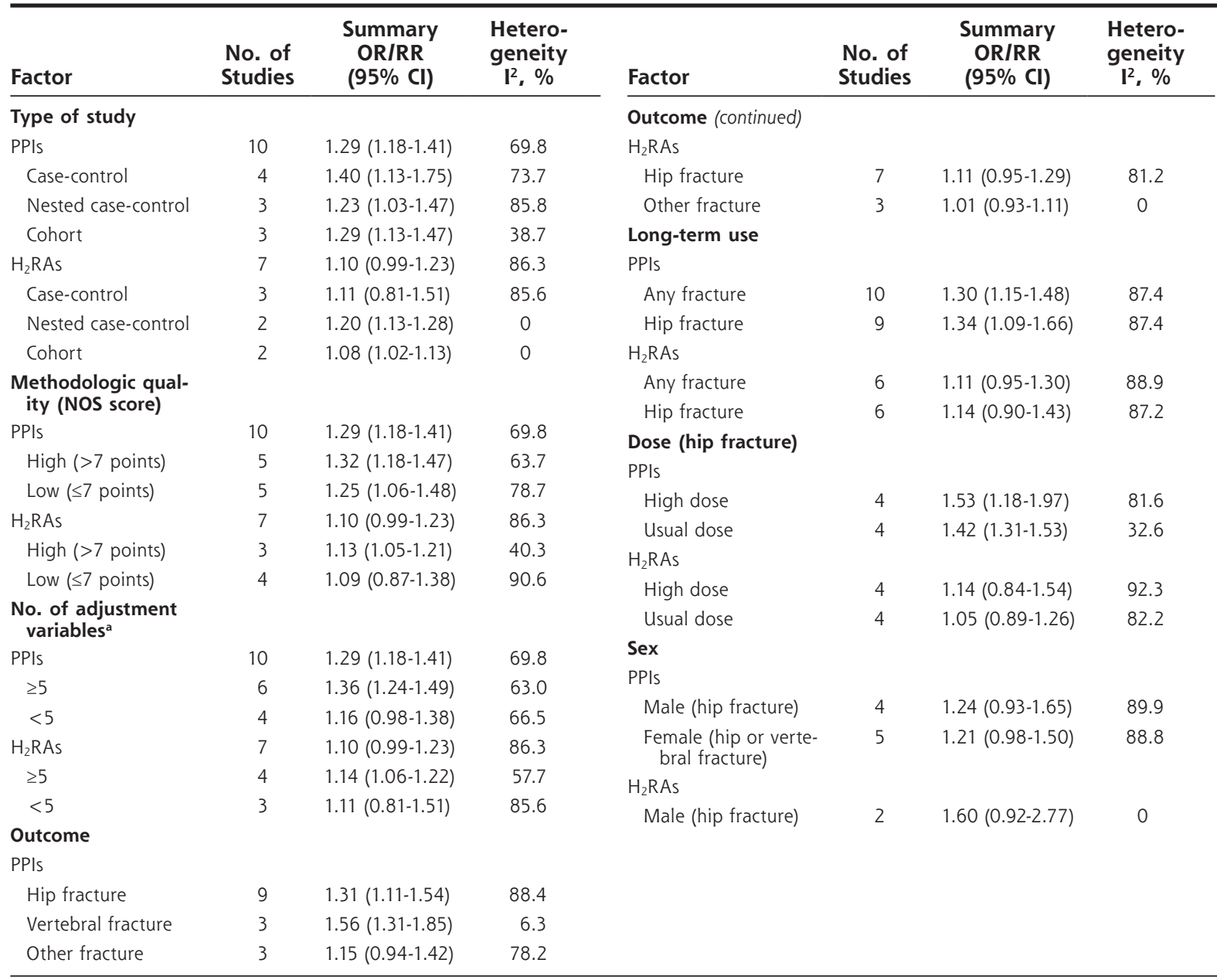

$\mathrm{Cl}=$ confidence interval; $\mathrm{H}_{2} \mathrm{RA}=$ histamine 2 receptor antagonist; na = not available; NOS = Newcastle-Ottawa Scale; OR = odds ratio; PPI = proton pump inhibitor; $\mathrm{RR}=$ relative risk.

a Of the following variables: age, sex, body mass index, alcohol, smoking, medications that might have affected the risk of osteoporosis or fracture, physical activity or exercise, prior fracture or low-trauma fracture, calcium supplement or antiosteoporotic medications, hormone replacement therapy, history of stomach surgery or digestive system disorders, osteoporosis, family history of osteoporotic fracture.

marginally no association between PPI use and fracture risk (adjusted OR $=1.16 ; 95 \% \mathrm{CI}, 0.98-1.38 ; \mathrm{I}^{2}=66.5 \%$; $\mathrm{n}=4$ ), but no significant association between $\mathrm{H}_{2} \mathrm{RA}$ use and fracture risk (adjusted $\mathrm{OR}=1.11 ; 95 \% \mathrm{CI}, 0.81$ $1.51 ; \mathrm{I}^{2}=85.6 \% ; \mathrm{n}=3$ ).

When we grouped studies by fracture outcome, we found a significant positive association between PPI use and hip fracture risk (adjusted $\mathrm{OR}=1.31 ; 95 \% \mathrm{CI}$, $1.11-1.54 ; \mathrm{I}^{2}=88.4 \% ; \mathrm{n}=9$ ) and vertebral fracture risk (adjusted $\mathrm{OR}=1.56 ; 95 \% \mathrm{CI}, 1.31-1.85 ; \mathrm{I}^{2}=6.3 \% ; \mathrm{n}=3$ ), whereas there was no significant association between PPI use and the risk of other fractures, or between $\mathrm{H}_{2} \mathrm{RA}$ use and hip and any fracture risk.

In subgroup meta-analyses by duration of use, long-term use of PPIs increased the risk of any fracture (adjusted OR $=1.30 ; 95 \% \mathrm{CI}, 1.15-1.48 ; \mathrm{n}=10$ ) and the risk of hip fracture (adjusted $\mathrm{OR}=1.34 ; 95 \% \mathrm{CI}, 1.09$ $1.66 ; \mathrm{n}=9$ ). There was no association between longterm use of $\mathrm{H}_{2}$ RAs and either of these outcomes.

When we grouped studies by dose, we observed a significantly increased risk of hip fracture for both high-dose use of PPIs (adjusted OR $=1.53$; 95\% CI, 1.18-1.97; $\mathrm{n}=4$ ) and usual-dose use of PPIs (adjusted $\mathrm{OR}=1.42 ; 95 \% \mathrm{CI}, 1.31-1.53 ; \mathrm{n}=4)$. In contrast, we found no association with hip fracture for either highdose or usual-dose use of $\mathrm{H}_{2}$ RAs.

Subgroup analyses by sex showed no significant association between PPI or $\mathrm{H}_{2} \mathrm{RA}$ use and hip fracture risk in men, or hip fracture or vertebral fracture risk in women. 
Table 3. Methodologic Quality of Studies, Based on the Newcastle-Ottawa Scale $(\mathrm{N}=11)$

\begin{tabular}{l} 
Selection \\
\cline { 2 - 6 }
\end{tabular}

\section{Publication Bias}

We found no statistically significant asymmetry in funnel plots, and the result of the Egger test was nonsignificant. Specifically, the Begg funnel plot was not asymmetrical, and the $P$ value for bias in the Egger test was .45 for PPIs and .43 for $\mathrm{H}_{2}$ RAs (data not shown), indicating no significant influence of publication bias among the included studies.

\section{DISCUSSION}

In this meta-analysis of observational studies, we found that the use of PPIs was associated with a moderate increase in the risk of fracture compared with nonuse of PPIs, whereas we did not observe any significant association between $\mathrm{H}_{2} \mathrm{RA}$ use and this risk. Similarly, long-term PPI use and any dose of PPIs increased the risk of fracture in a meta-analysis of all the studies reporting duration of use and dose, whereas neither long-term use and nor use of any dose of $\mathrm{H}_{2}$ RAs was significantly associated with fracture risk.

We did not find any significant association between use of $\mathrm{H}_{2} \mathrm{RAs}$, which are less potent acid inhibitors than PPIs, and fracture risk. On average, $\mathrm{H}_{2} \mathrm{RAs}$ block only $70 \%$ of gastric acid production, whereas PPIs suppress acid production by up to $98 \%{ }^{33,38,54}$ More prolonged exposure to $\mathrm{H}_{2} \mathrm{RAs}$ may be necessary to observe similar effects on fracture risk, but we did not find long-term use of these agents to increase risk. These results suggest that $\mathrm{H}_{2} \mathrm{RAs}$ and PPIs may have differing effects on bone metabolism. Some studies suggest that $\mathrm{H}_{2} \mathrm{RAs}$ may have antiresorptive properties ${ }^{55,56}$ and even increase bone mineral density, which could decrease fracture risk. ${ }^{39}$ Cimetidine also has been shown to prevent osteoclast differentiation induced by histamine. ${ }^{57,58}$ Because of the mixed effects of $\mathrm{H}_{2} \mathrm{RAs}$ on bone health, there have been inconsistent results regarding long-term use of these drugs and fracture risk ${ }^{22,39,42,49}$ or bone mineral density. ${ }^{59}$ In contrast, PPIs have been shown to inhibit gastric proton pumps at physiologic concentrations, whereas the inhibition of osteoclast and other tissue $\mathrm{H}+/ \mathrm{K}+$ ATPase activity, such as osteoclast proton pumps, is much less pronounced. ${ }^{60}$ We did find, however, that the use of $\mathrm{H}_{2} \mathrm{RAs}$ was associated with a mild increase in fracture risk in studies having high-quality methodology (NOS score $>7$ ) and in studies adjusting for at least 5 variables, but not in studies having low-quality methodology and adjusting for fewer than 5 variables. Further research in this area is needed.

Interestingly, the subgroup meta-analyses by the number of adjustment variables showed a significantly increased risk of fracture for both PPI and $\mathrm{H}_{2} \mathrm{RA}$ use when the data were adjusted for at least 5 variables. The results for $\mathrm{H}_{2} \mathrm{RAs}$ conflict with those of Vestergaard et al, ${ }^{39}$ who reported a statistically significant protective effect with use of these drugs for any fracture and hip fracture. The positive association we found between $\mathrm{H}_{2} \mathrm{RA}$ use and fracture risk in studies with a high level of statistical adjustment may also be 
consistent with the marginal association we observed in high-quality studies (NOS score $>7$ ).

$\mathrm{Yu}$ et $\mathrm{al}^{50}$ showed a possible interaction of PPI use and calcium supplement use on the risk of nonspine fractures in men. In stratified analyses, PPI use was associated with an increase in fracture risk among men who were not taking calcium supplements, but not among men who were taking them. In contrast, no significant interactions were found for fracture outcomes in women. The clinical implication of this finding is that PPIs prescribed along with calcium supplement might be able to prevent osteoporosis in older men.

Kaye and $\mathrm{Jick}^{42}$ restricted the phase 2 part of their study to patients with no major medical risk factors for fracture and found no association of PPI use and fracture. This finding can be interpreted as evidence that PPI use is not associated with a substantially increased risk of fracture. If a causal association between use and fracture risk indeed existed to a clinically relevant degree, one would expect to find this association also in this group of patients with a low a priori fracture risk. It cannot be concluded that PPI use is not associated with an altered fracture risk in patients at high risk of fractures, however, as this patient subset was not included in the phase 2 study. In addition, exclusion of patients with direct risk factors for factures, such as previous fracture and osteoporosis, can be problematic if these diseases are on the causal pathway and not necessarily confounders. ${ }^{61}$

Our meta-analysis has several strengths. First, it is the most comprehensive meta-analysis on the use of ASDs and fracture risk to date. Second, it examines the associations in greater detail by stratifying by the type of agent (PPI or $\mathrm{H}_{2} \mathrm{RA}$ ) and the type of outcome (hip or vertebral fracture), as well as by dose and duration of use. On the other hand, our meta-analysis also has several limitations. First, observational studies are considered to have greater potential for bias. To compensate for this limitation, we conducted subgroup analysis according to various factors. Second, the Egger test is known to lack power, reducing our ability to detect potential publication bias. Third, we did not have access to individual data on nutrients that might affect the risk of fracture. The dietary habits of ASD users may differ from those of nonusers because of intolerance secondary to gastritis. Furthermore, the dietary acid load can affect bone metabolism. Finally, we could not evaluate the effect of underlying gastric diseases in each patient because these data were not given in each study. Bone alteration may be related to the underlying gastric disease. The prevalence of $H$ pylori infection has been found to be high in men with osteoporosis, ${ }^{62}$ and this infection may be present in patients taking ASDs. H pylori infection can induce a permanent inflammatory response, that is, a gastric and systemic increase in indexes of inflammation. This mechanism has been implicated in some extragastric manifestations in $\mathrm{H}$ pylori-infected patients. ${ }^{62}$

A major limitation of our meta-analysis of observational studies is the possibility of uncontrolled confounding. Our findings should therefore be confirmed by further prospective studies including RCTs that are designed specifically with large sample sizes and long follow-up durations to test the effect of ASDs on the risk of fracture.

In conclusion, we found that in a meta-analysis of case-control, nested case-control, and cohort studies, PPI use modestly increased fracture risk, whereas $\mathrm{H}_{2} \mathrm{RA}$ use did not. An OR or RR of less than 2, as seen in this study, is generally considered to be a weak or low-magnitude association. Nevertheless, even small increases in these values for common diseases may have important public health implications. Clinicians should therefore carefully consider their decision to prescribe PPIs for patients at elevated risk for fracture, especially women older than 65 years of age. ${ }^{63-65}$ It is not necessary to treat patients to the point of an achlorhydric state to resolve acid reflux symptoms, so we recommend that drug doses be chosen thoughtfully with consideration of what is necessary to achieve desired therapeutic goals.

To read or post commentaries in response to this article, see it online at http://www.annfammed.org/cgi/content/full/9/3/257.

Submitted October 11, 2010; submitted, revised December 16, 2010; accepted January 6, 2011.

Key words: Proton pump inhibitors; $\mathrm{H}_{2}$-receptor antagonists; fracture risk; meta-analysis

Funding support: This work was supported by a National Research Foundation of Korea (NRF) Grant funded by the Korean government (grant 2010-0004429).

\section{References}

1. CAG Clinical Affairs Committee. Community-acquired pneumonia and acid-suppressive drugs: position statement. Can J Gastroenterol. 2006;20(2):119-121, 123-125.

2. Eastell R, Lambert H. Strategies for skeletal health in the elderly. Proc Nutr Soc. 2002;61(2):173-180.

3. Seeman E, Bianchi G, Adami S, Kanis J, Khosla S, Orwoll E. Osteoporosis in men-consensus is premature. Calcif Tissue Int. 2004; 75(2):120-122.

4. Roughead EE, Ramsay EN, Pratt NL, Ryan P, Gilbert AL. Protonpump inhibitors and the risk of antibiotic use and hospitalisation for pneumonia. Med J Aust. 2009;190(3):114-116.

5. Jacobson BC, Ferris TG, Shea TL, Mahlis EM, Lee TH, Wang TC. Who is using chronic acid suppression therapy and why? Am J Gastroenterol. 2003;98(1):51-58.

6. Miyamoto M, Haruma K, Kuwabara M, Nagano M, Okamoto T, Tanaka M. Long-term gastroesophageal reflux disease therapy improves reflux symptoms in elderly patients: five-year prospective study in community medicine. J Gastroenterol Hepatol. 2007;22(5): 639-644. 
7. Tuukkanen J, Väänänen HK. Omeprazole, a specific inhibitor of $\mathrm{H}+-\mathrm{K}+-$ ATPase, inhibits bone resorption in vitro. Calcif Tissue Int. 1986;38(2):123-125.

8. Zaidi M. Modularity of osteoclast behaviour and "mode-specific" inhibition of osteoclast function. Biosci Rep. 1990;10(6):547-556.

9. Sahara T, Itoh K, Debari K, Sasaki T. Specific biological functions of vacuolar-type $\mathrm{H}(+)$-ATPase and lysosomal cysteine proteinase, cathepsin K, in osteoclasts. Anat Rec A Discov Mol Cell Evol Biol. 2003;270(2):152-161.

10. Sasaki T. Recent advances in the ultrastructural assessment of osteoclastic resorptive functions. Microsc Res Tech. 1996;33(2):182-191.

11. Shibata T, Amano H, Yamada S, Ohya K. Mechanisms of proton transport in isolated rat osteoclasts attached to bone. J Med Dent Sci. 2000;47(3):177-185.

12. Gagliardi S, Nadler G, Consolandi E, et al. 5-(5,6-Dichloro-2indolyl)-2-methoxy-2,4-pentadienamides: novel and selective inhibitors of the vacuolar $\mathrm{H}+$-ATPase of osteoclasts with bone antiresorptive activity. J Med Chem. 1998;41(10):1568-1573.

13. Rzeszutek K, Sarraf F, Davies JE. Proton pump inhibitors control osteoclastic resorption of calcium phosphate implants and stimulate increased local reparative bone growth. J Craniofac Surg. 2003;14(3):301-307.

14. Sundquist K, Lakkakorpi P, Wallmark B, Väänänen K. Inhibition of osteoclast proton transport by bafilomycin A1 abolishes bone resorption. Biochem Biophys Res Commun. 1990;168(1):309-313.

15. Visentin L, Dodds RA, Valente $M$, et al. A selective inhibitor of the osteoclastic $\mathrm{V}-\mathrm{H}(+)$-ATPase prevents bone loss in both thy roparathyroidectomized and ovariectomized rats. J Clin Invest. 2000;106(2):309-318

16. Xu J, Feng HT, Wang C, et al. Effects of bafilomycin A1: an inhibitor of vacuolar $\mathrm{H}(+)$-ATPases on endocytosis and apoptosis in RAW cells and RAW cell-derived osteoclasts. J Cell Biochem. 2003;88(6):1256-1264.

17. Mizunashi K, Furukawa Y, Katano K, Abe K. Effect of omeprazole, an inhibitor of $\mathrm{H}+, \mathrm{K}(+)$-ATPase, on bone resorption in humans. Calcif Tissue Int. 1993;53(1):21-25.

18. Shangraw RF. Factors to consider in the selection of a calcium supplement. Public Health Rep. 1989;104(Suppl):46-50.

19. Bo-Linn GW, Davis GR, Buddrus DJ, Morawski SG, Santa Ana C, Fordtran JS. An evaluation of the importance of gastric acid secre tion in the absorption of dietary calcium. J Clin Invest. 1984;73(3): 640-647.

20. Nordin BE. Calcium and osteoporosis. Nutrition. 1997;13(7-8): 664-686.

21. Wood RJ, Serfaty-Lacrosniere C. Gastric acidity, atrophic gastritis, and calcium absorption. Nutr Rev. 1992;50(2):33-40.

22. Yang Y-X, Lewis JD, Epstein S, Metz DC. Long-term proton pump inhibitor therapy and risk of hip fracture. JAMA. 2006;296(24):2947-2953

23. Targownik LE, Lix LM, Metge CJ, Prior HJ, Leung S, Leslie WD. Use of proton pump inhibitors and risk of osteoporosis-related fractures. CMAJ. 2008;179(4):319-326.

24. Zhang Y, Lai WP, Wu CF, Favus MJ, Leung PC, Wong MS. Ovariectomy worsens secondary hyperparathyroidism in mature rats during low-Ca diet. Am J Physiol Endocrinol Metab. 2007;292(3):E723-E731.

25. Ueyama T, Shirasawa N, Ito T, Tsuruo Y. Estrogen-producing steroidogenic pathways in parietal cells of the rat gastric mucosa. Life Sci. 2004;74(18):2327-2337.

26. Ueyama T, Shirasawa N, Numazawa M, et al. Gastric parietal cells: potent endocrine role in secreting estrogen as a possible regulator of gastro-hepatic axis. Endocrinology. 2002;143(8):3162-3170.

27. Campbell-Thompson M, Reyher KK, Wilkinson LB. Immunolocalization of estrogen receptor alpha and beta in gastric epithelium and enteric neurons. J Endocrinol. 2001;171(1):65-73.
28. Sozzi M, Valentini M, Figura N, et al. Atrophic gastritis and intestinal metaplasia in Helicobacter pylori infection: the role of CagA status. Am J Gastroenterol. 1998;93(3):375-379.

29. Sakata I, Tanaka T, Yamazaki M, Tanizaki T, Zheng Z, Sakai T. Gastric estrogen directly induces ghrelin expression and production in the rat stomach. J Endocrinol. 2006;190(3):749-757.

30. Matsubara M, Sakata I, Wada R, Yamazaki M, Inoue K, Sakai T. Estrogen modulates ghrelin expression in the female rat stomach. Peptides. 2004;25(2):289-297.

31. Fukushima N, Hanada R, Teranishi H, et al. Ghrelin directly regulates bone formation. J Bone Miner Res. 2005;20(5):790-798.

32. Richards JB, Goltzman D. Proton pump inhibitors: balancing the benefits and potential fracture risks. CMAJ. 2008;179(4):306-307.

33. Schuler A. Risks versus benefits of long-term proton pump inhibitor therapy in the elderly. Geriatr Nurs. 2007;28(4):225-229.

34. Landahl S, Andersson T, Larsson M, et al. Pharmacokinetic study of omeprazole in elderly healthy volunteers. Clin Pharmacokinet. 1992;23(6):469-476.

35. Marshall BJ. Helicobacter pylori. Am J Gastroenterol. 1994;89(8 Suppl):S116-S128.

36. Ivanovich $\mathrm{P}$, Fellows $\mathrm{H}$, Rich $\mathrm{C}$. The absorption of calcium carbonate. Ann Intern Med. 1967;66(5):917-923.

37. Recker RR. Calcium absorption and achlorhydria. N Engl J Med. 1985;313(2):70-73.

38. Colin-Jones DG. The role and limitations of $\mathrm{H} 2$-receptor antagonists in the treatment of gastro-oesophageal reflux disease. Aliment Pharmacol Ther. 1995;9(Suppl 1):9-14.

39. Vestergaard P, Rejnmark L, Mosekilde L. Proton pump inhibitors, histamine $\mathrm{H} 2$ receptor antagonists, and other antacid medications and the risk of fracture. Calcif Tissue Int. 2006;79(2):76-83.

40. Yu EW, Blackwell T, Ensrud KE, et al. Acid-suppressive medication and risk of bone loss and fracture in older adults. Calcif Tissue Int. 2008;83(4):251-259.

41. Roux C, Briot K, Gossec L, et al. Increase in vertebral fracture risk in postmenopausal women using omeprazole. Calcif Tissue Int. 2009;84(1):13-19.

42. Kaye JA, Jick H. Proton pump inhibitor use and risk of hip fractures in patients without major risk factors. Pharmacotherapy. 2008;28(8):951-959.

43. Stroup DF, Berlin JA, Morton SC, et al. Meta-analysis of observational studies in epidemiology: a proposal for reporting. Metaanalysis Of Observational Studies in Epidemiology (MOOSE) group. JAMA. 2000;283(15):2008-2012.

44. Schoofs MW, van der Klift M, Hofman A, et al. Thiazide diuretics and the risk for hip fracture. Ann Intern Med. 2003;139(6):476-482.

45. Van Staa TP, Leufkens HG, Abenhaim L, Zhang B, Cooper C. Use of oral corticosteroids and risk of fractures.J Bone Miner Res. 2000;15(6):993-1000

46. Wells GA, Shea B, O'Connell D, et al. The Newcastle-Ottawa Scale (NOS) for assessing the quality of non-randomized studies in metaanalyses. http://www.ohri.ca/programs/clinical_epidemiology/ oxford.htm. Accessed December 12, 2010.

47. Higgins JP, Thompson SG. Quantifying heterogeneity in a metaanalysis. Stat Med. 2002;21(11):1539-1558.

48. DerSimonian R, Laird N. Meta-analysis in clinical trials. Control Clin Trials. 1986;7(3):177-188.

49. Grisso JA, Kelsey JL, O’Brien LA, et al; Hip Fracture Study Group. Risk factors for hip fracture in men. Am J Epidemiol. 1997;145(9): 786-793.

50. Corley DA, Kubo A, Zhao W, Quesenberry C. Proton pump inhibitors and histamine-2 receptor antagonists are associated with hip fractures among at-risk patients. Gastroenterology. 2010;139(1):93-101. 
51. Gray SL, LaCroix AZ, Larson J, et al. Proton pump inhibitor use, hip fracture, and change in bone mineral density in postmenopausal women: results from the Women's Health Initiative. Arch Intern Med. 2010;170(9):765-771.

52. Pouwels $S$, Lalmohamed $A$, Souverein $P$, et al. Use of proton pump inhibitors and risk of hip/femur fracture: a population-based casecontrol study. Osteoporos Int. 2011;22(3):903-910.

53. Chiu HF, Huang YW, Chang CC, Yang CY. Use of proton pump inhibitors increased the risk of hip fracture: a population-based case-control study. Pharmacoepidemiol Drug Saf. 2010;19(11): 1131-1136.

54. Olbe L, Cederberg C, Lind T, Olausson M. Effect of omeprazole on gastric acid secretion and plasma gastrin in man. Scand J Gastroenterol Suppl. 1989;166:27-32, discussion 41-42.

55. Lesclous P, Guez D, Baroukh B, Vignery A, Saffar JL. Histamine participates in the early phase of trabecular bone loss in ovariectomized rats. Bone. 2004;34(1):91-99.

56. Lesclous P, Guez D, Saffar JL. Short-term prevention of osteoclastic resorption and osteopenia in ovariectomized rats treated with the $\mathrm{H}(2)$ receptor antagonist cimetidine. Bone. 2002;30(1):131-136.

57. Yamaura K, Yonekawa T, Nakamura T, Yano S, Ueno K. The histamine $\mathrm{H} 2$-receptor antagonist, cimetidine, inhibits the articular osteopenia in rats with adjuvant-induced arthritis by suppressing the osteoclast differentiation induced by histamine. J Pharmacol Sci. 2003:92(1):43-49.
58. Dobigny C, Saffar JL. $\mathrm{H} 1$ and $\mathrm{H} 2$ histamine receptors modulate osteoclastic resorption by different pathways: evidence obtained by using receptor antagonists in a rat synchronized resorption model. J Cell Physiol. 1997;173(1):10-18.

59. Adachi Y, Shiota E, Matsumata T, Iso Y, Yoh R, Kitano S. Bone mineral density in patients taking $\mathrm{H} 2$-receptor antagonist. Calcif Tissue Int. 1998;62(4):283-285.

60. Mattsson JP, Väänänen K, Wallmark B, Lorentzon P. Omeprazole and bafilomycin, two proton pump inhibitors: differentiation of their effects on gastric, kidney and bone $\mathrm{H}(+)$-translocating ATPases. Biochim Biophys Acta. 1991;1065(2):261-268.

61. Bodmer M, Meier C, Kraenzlin ME, Meier CR. Proton pump inhibitors and fracture risk: true effect or residual confounding? Drug Saf. 2010;33(10):843-852

62. Figura N, Gennari L, Merlotti D, et al. Prevalence of Helicobacter pylori infection in male patients with osteoporosis and controls. Dig Dis Sci. 2005;50(5):847-852

63. Gullberg B, Johnell O, Kanis JA. World-wide projections for hip fracture. Osteoporos Int. 1997;7(5):407-413.

64. Kanis JA. The incidence of hip fracture in Europe. Osteoporos Int. 1993;3(Suppl 1):10-15.

65. O'Connell MB, Madden DM, Murray AM, Heaney RP, Kerzner LJ. Effects of proton pump inhibitors on calcium carbonate absorption in women: a randomized crossover trial. Am J Med. 2005;118(7): 778-781. 